\title{
Ecological and conservation aspects of bycatch fishes: An evaluation of shrimp fisheries impacts in Northeastern Brazil
}

\author{
Rafaela Passarone ${ }^{1,2 *}$, Kátia Cristina Aparecido ${ }^{2}$, Leandro Nolé Eduardo ${ }^{2,3}$, Alex Souza Lira ${ }^{2,4}$, \\ Lucas Vinícius Santos Silva², Anne K. S. Justino², Cecília Craveiro², Emanuell F. Silva ${ }^{5}$, Flávia \\ Lucena-Frédou ${ }^{2}$
}

\author{
${ }^{1}$ Universidade Federal Rural de Pernambuco, Departamento de Ecologia \\ (Rua Dom Manuel de Medeiros, s/n, Dois Irmãos, Recife - PE, 52171-900, Brasil) \\ ${ }^{2}$ Universidade Federal Rural de Pernambuco, Departamento de Pesca e Aquicultura \\ (Rua Dom Manuel de Medeiros, s/n, Dois Irmãos, Recife - PE, 52171-900, Brasil) \\ ${ }^{3}$ Institut de Recherche pour le Développement (IRD) - Marine Biodiversity, Exploitation and Conservation (MARBEC), Centre National \\ de la Recherche Scientifique (CNRS), Institut Français de Recherche pour l'Exploitation de la Mer (IFREMER) \\ (87 Avenue Jean Monnet, 34200, Sète, France) \\ ${ }^{4}$ Université de Bretagne Occidentale (UBO), Laboratoire des Sciences de l'Environnement Marin (CNRS, UBO, IRD, Ifremer), Institut \\ Universitaire Européen de la Mer, Technopôle \\ (Brest-Iroise, Rue Dumont d'Urville, 29280, Plouzané, France) \\ ${ }^{5}$ Instituto Federal de Educação Ciência e Tecnologia da Paraíba, Campus Cabedelo \\ (Rua Santa Rita de Cássia, S/N, Jardim Jericó, Cabedelo - PB, 58310-000, Brasil)
}

*Corresponding author: rpassarone@gmail.com

Fishes accidentally caught, commonly known as bycatch, usually have no economic importance and are not reported in official statistics, being frequently discarded at sea (Crowder and Murawski, 1998). This bycatch contributes to alterations in the ecosystem, decline of populations, catch of juveniles and endangered species, threatening many marine populations (Pascoe, 1997). Despite significant efforts carried out towards the mitigation of the bycatch (Hazen et al., 2018), basic biological information is lacking for many non-target species, hampering the assessment of the real impact of this incidental catch and application of sustainable management actions in an ecosystem viewpoint.

Length-weight relationships (LWR) may be used to infer body condition indices, to estimate the fish weight from a known length and vice versa (Froese, 2006) and is often used as an input parameter in stock assessment and ecological modeling (Vaz-dos-Santos and RossiWongtschowski, 2013).

In the Northeastern of Brazil, the shrimp fisheries are predominantly artisanal, carried out mainly by motorized artisanal trawling boats and, in some cases, beach seine

Submitted on: 3/October/2019

Approved on: 17/October/2019

http://dx.doi.org/10.1590/S1679-87592019029106713

Editor: June Ferraz Dias nets (Dias Neto, 2011). This activity is focused on shallow waters and has great social-economic importance, since approximately 100,000 persons depend directly or indirectly of this fishery for their living (Santos et al., 2006). Previous studies focusing on the bycatch species in the northeast of Brazil (Silva-Júnior et al., 2013; Eduardo et al., 2019; Lira et al., in press) provided valuable biological and population information of a variety of species. However, many species still lack basic knowledge that is required for management and conservation actions, such as length-weight relationships and size at first gonadal maturity and also indicators of the ecological roles of the fish species, especially those related to the balancing of the marine food web which may influence the composition of this ecosystem (Elliott et al., 2007).

In this study, we provide LWR information and a review of literature addressing the size at first maturity, conservation status, and trophic and functional guilds of thirty-three fishes captured incidentally in a shrimp fishery in Northeast Brazil. We expect that this information may contribute to the general biological knowledge and hence to the sustainable management and conservation of these bycatch fish species.

The study was conducted in the municipality of Lucena $\left(6^{\circ} 53^{\prime} 50^{\prime \prime} \mathrm{S}\right.$ and $\left.34^{\circ} 51^{\prime} 01^{\prime \prime} \mathrm{W}\right)$ on the coast of the state of Paraíba, Northeastern Brazil (Figure 1). 




Figure 1. Map of the study area, coast of the state of Paraiba, Brazil.

Specimens were collected monthly from December 2016 to November 2017 using one of the local beach seines (out of 8), representative of the overall fleet, which is the predominant fishing modality in the region to catch shrimp. This net (side length of body mesh: $2 \mathrm{~cm}$, side length of cod-end mesh: $1.5 \mathrm{~cm}$, entrance dimensions horizontal $x$ vertical: $120 \times 6 \mathrm{~m}$ ) was deployed from a small, nonmotorized craft. Two trawls (50 minutes from the moment of the deployment of the net to the end of the operation) were performed monthly. Trawls were carried out from 6 $\mathrm{m}$ deep to the surf zone and a maximum distance of 500 $\mathrm{m}$ from shore.

Individuals were identified, measured (nearest 0.1 $\mathrm{cm}$ total length TL) and weighed (nearest $0.01 \mathrm{~g}$ in total weight TW). The LWR values were estimated for species with $\mathrm{n}>30$ specimens, using the equation: $\mathrm{TW}=a \times \mathrm{TL}^{b}$, where TW is the total weight (in g); TL is the total length (in $\mathrm{cm}$ ); $a$ is the intercept of the regression curve (intercept of TW when TL is zero or initial growth coefficient) and $b$ is the regression slope. This coefficient generally varies between 2.5 and 3.5 , and the relation is considered isometric when $b=3$ (all fish increase at the same rate), positive allometric when $b>3$ (increases more in weight than predicted by its increase in length) or negative allometric when $b<3$ (fish increases less in weight than predicted by its increase in length) (Froese, 2006; Froese et al., 2011). Prior to calculation of the LWR, outliers for each species were graphically identified and removed using TL versus TW plots (Froese and Binohlan, 2000). The significance of the regression was tested by ANOVA and the degree of association between TW and SL was calculated by the determination coefficient $\left(\mathrm{r}^{2}\right)$.

For each species, it was recorded information on size at first maturity $\left(\mathrm{L}_{50}\right)$ and maximum length $\left(\mathrm{L}_{\max }\right)$, available in the literature. Species were classified according to estuarine use functional groups (EUFG) as proposed by Elliott et al. (2007): marine straggler (MS), marine migrants (MM) and estuarine species (ES), and by the feeding mode functional groups (FMFG), based on information contained in the literature on food strategies, according to the categories proposed by Elliott et al. (2007): zooplanktivore (ZP), detritivore (DV), piscivorous (PV), zoobenthivore (ZB), herbivore (HV) and omnivore (OV). In addition, the conservation status of the species recorded in this study were based on the International Union for Conservation of Nature (IUCN) Red List criteria, accessed by classification at the regional level (ICMBio, 2018), which comprises 10 categories: extinct (EX), regionally extinct (RE), extinct in the wild (EW), critically endangered (CR), endangered (EN), vulnerable (VU), near threatened (NT), least concern (LC), data deficient (DD) and not evaluated (NE).

A total of 10,992 individuals of 11 families and 4 orders and 33 species were analyzed (Table 1). According to the IUCN classification, 29 species were categorized as least concern (LC), 3 species as data deficient (DD) (Menticirrhus americanus, Ophioscion punctatissimus and Bagre marinus) and 1 species as near threatened (NT) (Bagre bagre), these last two categories deserving attention for management and conservation purposes (Table 1).

All LWR were highly significant $(p<0.01)$, with the coefficient of determination $\left(\mathrm{r}^{2}\right)$ ranging from 0.901 and 0.989 . The value of the parameter $(b)$ ranged between 2.45 for O. mucronatus and 3.498 from A. spinifer. Except for O. mucronatus, all species analysed in this study had the allometric coefficient $(b)$ between the expected range of 2.5 to 3.5 (Froese, 2006). The allometric coefficient (b) for the length-weight ratio reflects intrinsic characteristics, and adaptive process of each species, as reproductive or environmental ontogenetic variations, and mainly, between sexes (Froese, 2006). 


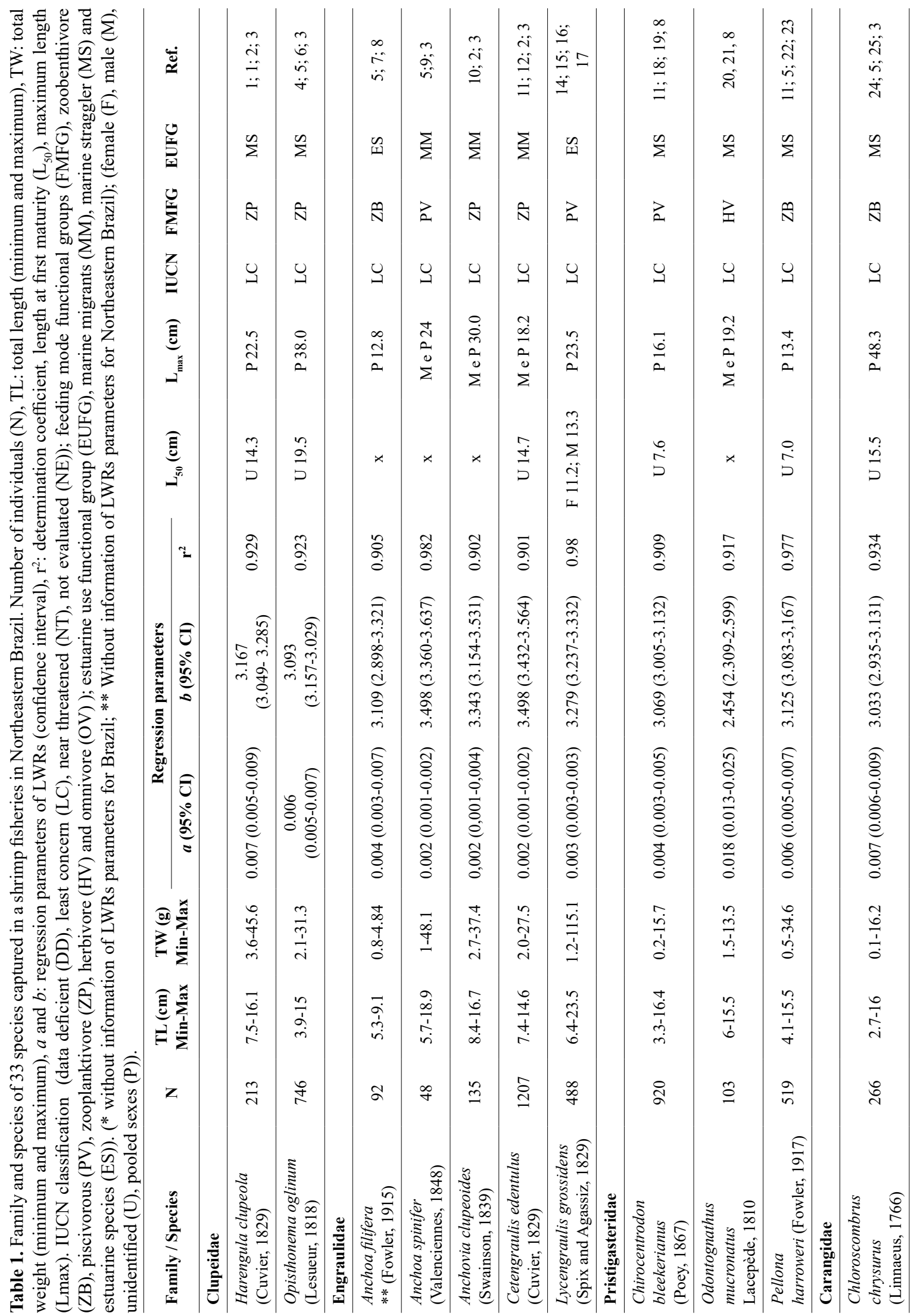




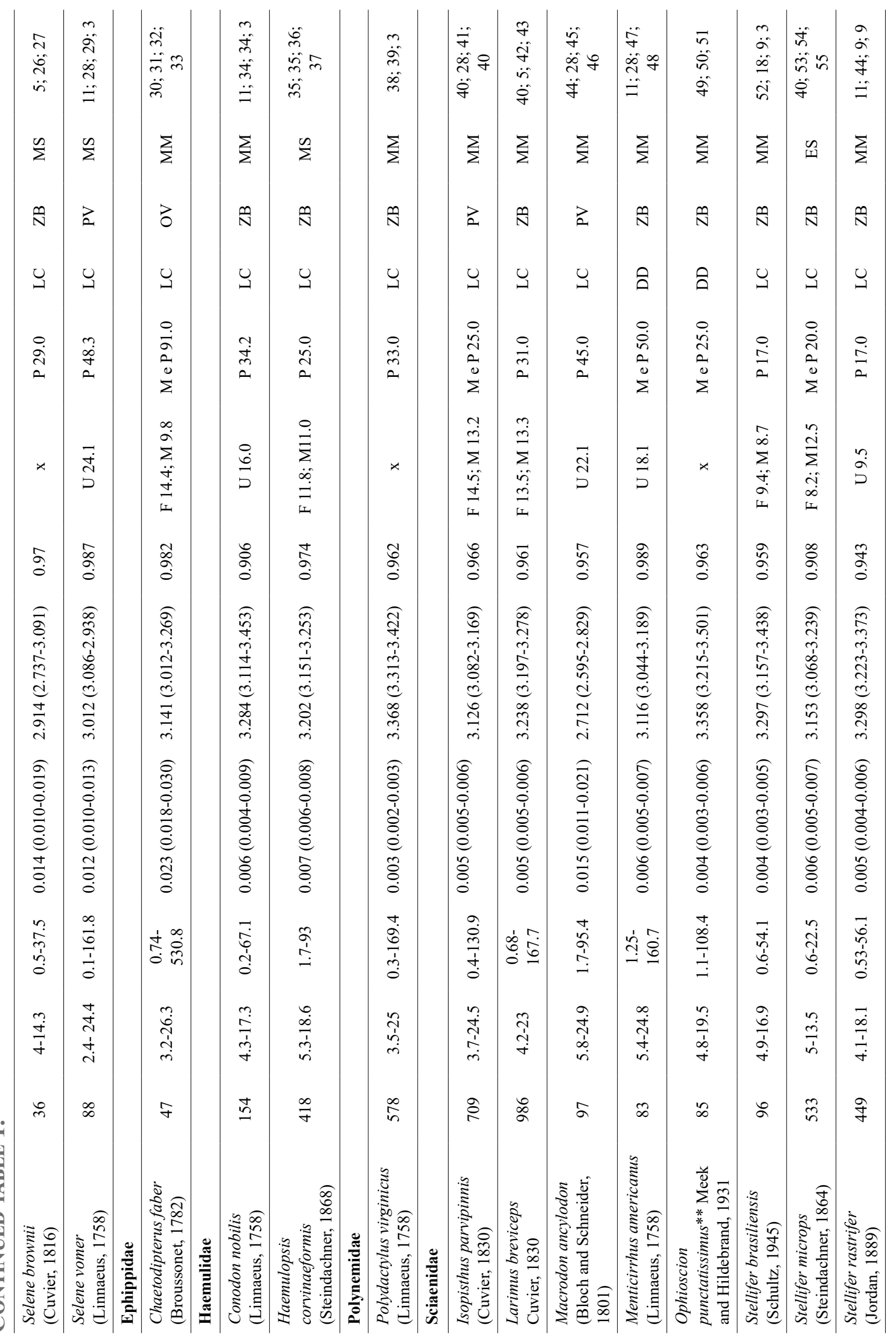




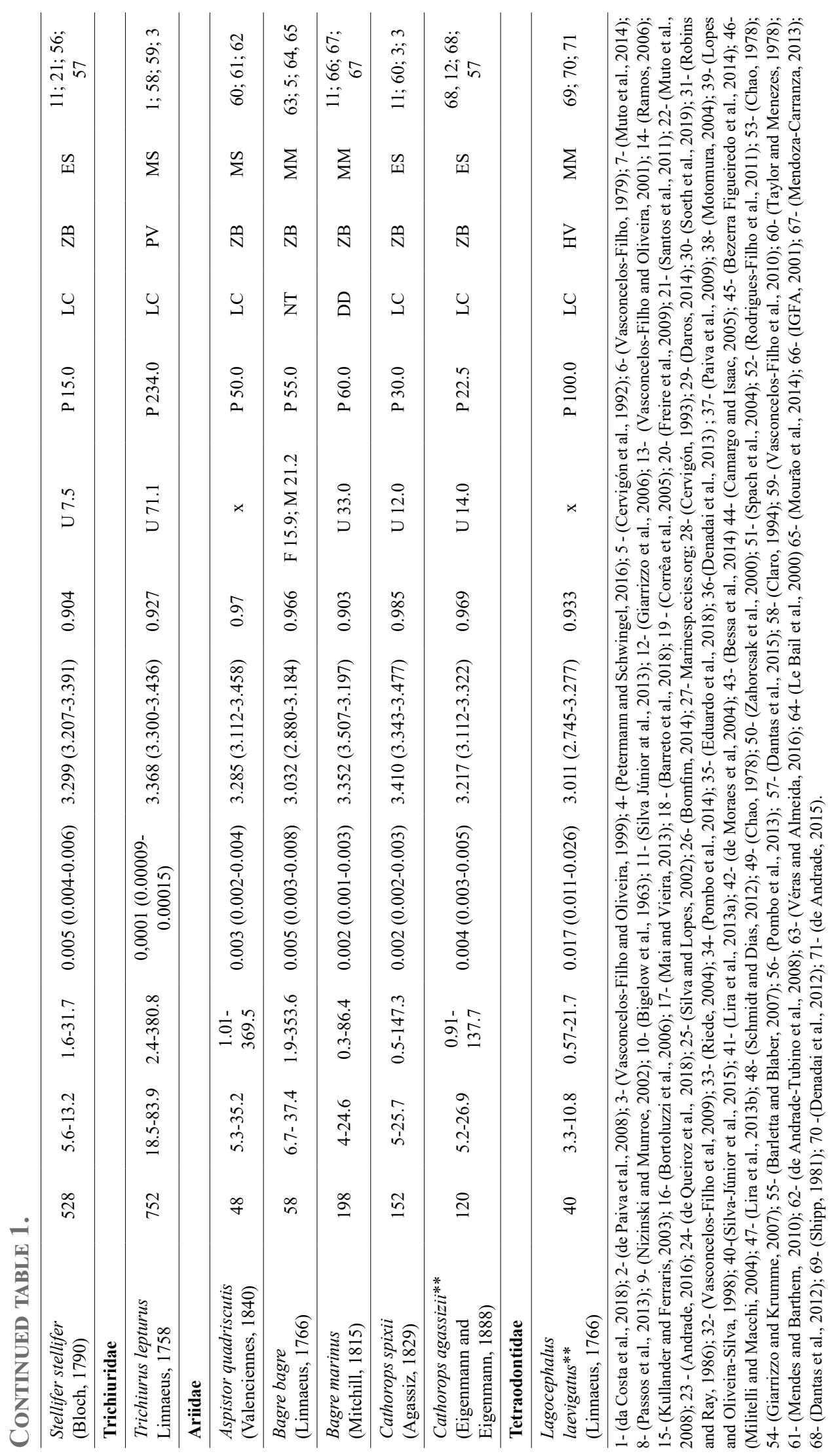


The classification in functional guilds is widely used to investigate the composition, and spatial-temporal distribution of ichthyofauna (Akin et al., 2005; Ferreira et al., 2019). This approach can be used to simplify the understanding of complex ecosystems by generating information about the hierarchical structure and connectivity (Garrison and Link, 2000; Angel and Ojeda, 2001; Franco et al., 2008; Nicolas et al., 2010) investigating anthropic stressors, including the effect of fishing (Auster and Link, 2009). According to the feeding mode functional groups (FMFG), 19 species were classified as zoobenthivore (ZB), 7 species as piscivorous (PV), 4 species zooplanktivore (ZP), 2 species herbivore (HV), and 1 species omnivore $(\mathrm{OV})$. The predation of detritivores organisms and the interaction with sedimentary organic matter carried out by zoobenthivores play an important role between primary consumers and higher trophic levels in the food web (Duarte and Andreata, 2003).

Lycengraulis grossidens, Chirocentrodon bleekerianus, Pellona harroweri and Stellifer rastrifer were caught above the maximum size described in the literature. We observed the predominant catch of specimens below the length of first maturation ( $89 \%$ of the individuals) (Table 1). The high catch of juveniles is characteristic of shrimp trawling. In Pernambuco, near to the study site, Silva Júnior et al. (2013) observed that $64 \%$ of the individuals caught are below the size of first maturation $\left(\mathrm{L}_{50}\right)$. The low selectivity of the fishing gear (Branco and Verani, 2006) and in our case the very shallow fishing zone may contribute to high juvenile catches, due to the lower swimming capacity at this stage, when compared to the adult specimens. In this study, according to the estuarine use functional group (EUFG), 16 species were categorized as marine migrants (MM), 11 species as marine straggler (MS) and 6 estuarine (ES) (Table 1). The high percentage of juveniles may also be related to the migratory behaviour of the species living in the adjacent open sea, migrating to the coastal and estuarine waters during spawning, using these areas for shelter and feeding (Pinheiro-Sousa et al., 2015), emphasizing the importance of the connectivity between the coastal and marine environment (Vasconcelos-Filho et al., 2009).

Overall, this study increases the knowledge on coastal fish, normally captured as bycatch, providing biological information useful for further studies in ecology, conservation, and fisheries assessment and management.

Thus, given the high catch of juveniles, species marine migrant and zoobenthivores in Lucena-PB, northeast Brazil, the present study reiterates the need for new approaches which appraise the species susceptibility, for a better evaluation of fishing impacts, such as, to improve the management measures, considering non-target species as a way of guaranteeing biodiversity and ecosystem stability.

\section{ACKNOWLEDGEMENTS}

This study was supported by the National Council for Scientific and Technological Development (CNPq), which has funded samples, analyses and provided student scholarship to Rafaela Passarone, Kátia Aparecido Cristina, Anne K. S. Justino, Leandro Nolé Eduardo, Cecília Craveiro, and Alex Souza Lira. Also, CNPq has provided a research grant for Flávia Lucena Frédou. The present study could not have been done without the work of all participants from the IFPBLucena and BIOIMPACT Laboratory. The author Leandro Nolé Eduardo is supported by FUNBIO and HUMANIZE under the grant "Programa Bolsas Funbio - Conservando o Futuro 2018 (011/2019)". The author Lucas Vinícius Santos Silva is supported by FACEPE - under the grant "Programa Institucional de Bolsas de Iniciação Científica".

\section{REFERENCES}

AKIN, S., BUHAN, E., WINEMILLER, K. O. \& YILMAZ, H. 2005. Fish assemblage structure of Koycegiz Lagoon-Estuary, Turkey: Spatial and temporal distribution patterns in relation to environmental variation. Estuarine, Coastal and Shelf Science, 64, 671-684.

ANDRADE, F. F. 2016. Assembleia de peixes do estuário do rio São Mateus - (ES): Variações Espaço-Temporais na Estrutura e Composição [Dissertartion]. São Mateus: Universidade Federal do Espírito Santo.

ANGEL, A. \& OJEDA, F. P. 2001. Structure and trophic organization of subtidal fish assemblages on the northern Chilean coast: The effect of habitat complexity. Marine Ecology Progress Series, 217, 81-91.

AUSTER, P. J. \& LINK, J. S. 2009. Compensation and recovery of feeding guilds in a northwest Atlantic shelf fish community. Marine Ecology Progress Series, 382, 163-172.

BARLETTA, M. \& BLABER, S. 2007. Comparison of fish assemblages and guilds in tropical habitats of the Embley (Indo-west Pacific) and caete (Western Atlantic) estuaries. Bulletin of Marine Science, 80, 647-680.

BARRETO, T. M. R. R., FREIRE, K. M. F., REIS-JÚNIOR, J. J. C., ROSA, L. C., CARVALHO-FILHO, A. \& ROTUNDO, M. M. 2018. Fish species caught by shrimp trawlers off the coast of Sergipe, in north-eastern Brazil, and their length-weight relations. Acta Ichthyologica Et Piscatoria, 48, 277-283.

BESSA, E., SANTOS, F. B., POMBO, M., DENADAI, M., FONSECA, M. \& TURRA, A. 2014. Population ecology, life history and diet of the shorthead drum Larimus breviceps in a tropical bight in southeastern Brazil. Journal of the Marine Biological Association of the United Kingdom, 94, 615-622. 
BEZERRA FIGUEIREDO, M., CARVALHO NETA, R. N. F., SILVA NUNES, J. L. \& DA SILVA DE ALMEIDA, Z. 2014. Feeding habits of Macrodon ancylodon (Actinopterygii, Sciaenidae) in northeast, Brazil. Revista de Biología Marina y Oceanografia, 49, 559-566.

BIGELOW, H. B., BRADBURY, M. G., DYMOND, J. R., GREELEY, J. R., HILDEBRAND, S. F., MEAD, G. W., MILLER, R. R., RIVAS, L. R., SCHROEDER, W. L., SUTTKUS, R. D. \& VLADYKOV, V. D. 1963. Fishes of the western North Atlantic. Part three, Marine Research, New Haven, Yale University.

BOMFIM, A. C. 2014. Bioecologia da ictiofauna marinha descartada pelo arrasto camaroeiro em praias da Bacia Potiguar, Brasil [dissertation]. Natal: Universidade Federal do Rio Grande do Norte.

BORTOLUZZI, T., ASCHENBRENNER, A. C., CAMILA, R., ROOS, D. C., LEPKOSKI, E. D., MARTINS, J. A., MAYKOL, G., QUEROL, E. \& QUEROL, M. V. 2006. Hábito alimentar da Sardinha Prata, Lycengraulis grossidens (Spix \& Agassiz, 1829), (Pisces, Engraulidae), Rio Uruguai Médio, Sudoeste do Rio Grande do Sul, Brasil. Biodiversidade Pampeana, 4, 11-23.

BRANCO, J. O., VERANI, J. R. \& PAULO, S. 2006. Análise quali-quantitativa da ictiofauna acompanhante na pesca do camarão sete-barbas, na Armação do Itapocoroy, Penha, Santa Catarina. Revista Brasileira de Zoologia, 23, 381-391.

CAMARGO, M. \& ISAAC, V. 2005. Reproductive biology and spatio-temporal distribution of Stellifer rastrifer, Stellifer naso and Macrodon ancylodon (Sciaenidae) in the Caeté estuary, northern Brazil. Brazilian Journal of Oceanography, $53,13-21$.

CERVIGÓN, F., CIPRIANI, R., FISCHER, W., GARIBALDI, L, HENDRICKX M., LEMUS, A. J., MÁRQUEZ, R., POUTIERS, J. M., ROBAINA, G. \& RODRIGUEZ, B. 1992. Guía de campo de las especies comerciales marinas y de aguas salobres de la costa septentrional de Sur América, Rome, FAO.

CERVIGÓN, F. 1993. Los peces marinos de Venezuela, Caracas, Fundación Científica Los Roques.

CHAO, L. N. 1978. Sciaenidae. In: FISCHER, W (ed.) FAO species identification sheets for fishery purpose. Western Central Atlantic (fishing area 31). Rome: FAO.

CLARO, R. 1994. Características generales de la ictiofauna. In: CLARO, R (ed.) Ecología de los peces marinos de Cuba. Puerto Morelos: Instituto de Oceanologia Academia de Ciencias de Cuba and Centro de Investigaciones de Quintana Roo (CIQRO), 55-70.

CORRÊA, C. E., CHAVES, P. D. T. \& GUIMARÃES, P. R. B. 2005. Biology of Chirocentrodon bleekerianus (Poey, 1867) (Clupeiformes: Pristigasteridae) in a continental shelf region of southern Brazil. Brazilian Archives of Biology and Technology, 48, 419-427.

CROWDER, L. B. \& MURAWSKI, S. A. 1998. Fisheries Bycatch: Implications for Management. Fisheries, 23, 8-17.

DA COSTA, M. R., TUBINO, R. A. \& MONTEIRO-NETO, C. 2018. Length-weight relations of juvenile and adult fishes (Actinopterygii) from shallow waters in the lower Guanabara bay Estuary, Brazil. Acta Ichthyologica Et Piscatoria, 48, 199-204.
DANTAS, D. V., BARLETTA, M., LIMA, A. R. A., RAMOS, J. D. A. A., DA COSTA, M. F. \& SAINT-PAUL, U. 2012. Nursery Habitat Shifts in an Estuarine Ecosystem: Patterns of Use by Sympatric Catfish Species. Estuaries and Coasts, 35, 587-602.

DANTAS, D. V, BARLETTA, M. \& COSTA, M. F. 2015. Feeding ecology and seasonal diet overlap between Stellifer brasiliensis and Stellifer stellifer in a tropical estuarine ecocline. Journal of Fish Biology, 86, 707-733.

DAROS, F. A. L. M. 2014. Estudo da ictiofauna costeira no litoral do Paraná e adjacências através de censos visuais e microquímica de otólitos [thesis]. Curitiba: Universidade Federal do Paraná.

DE ANDRADE, A. C., SANTOS, S. R., VERANI, J. R., \& VIANNA, M. 2015. Guild composition and habitat use by Tetraodontiformes (Teleostei, Acanthopterygii ) in a south-western Atlantic tropical estuary. Marine Biological Association of the United Kingdom, 96, 1251-1264.

DE ANDRADE-TUBINO, M. F., RIBEIRO, A. L. R. \& VIANNA, M. 2008. Organização Espaço-Temporal Das Ictiocenoses Demersais Nos Ecossistemas Estuarinos Brasileiros: Uma Síntese. Oecologia Australis, 12, 640-661.

DE MORAES, L. E., LOPES, P. R. D. \& OLIVEIRA-SILVA, J. T. 2004. Alimentação de Juvenis de Larimus breviceps (Cuvier, 1830) (Pices: Actinopterygii: Scianidae) na praia de Ponta da Ilha, (Ilha de Itaparica, Bahia). Revista Ciências Exatas e Naturais, 6, 246-256.

DENADAI, M. R., SANTOS, F. B., BESSA, E., BERNARDES, L. P. \& TURRA, A. 2012. Population biology and diet of the puffer fish Lagocephalus laevigatus (Tetraodontiformes: Tetraodontidae) in Caraguatatuba Bay, south-eastern Brazil. Journal of the Marine Biological Association of the United Kingdom, 92, 407-412.

DENADAI, M. R., SANTOS, F. B., BESSA, E., FERNANDEZ, W. S., LORCA, L. \& TURRA, A. 2013. Population biology and diet of Pomadasys corvinaeformis (Perciformes: Pomadasyidae) in Caraguatatuba Bay, Southeastern Brazil. Revista de Biologia Tropical, 61, 1935-1945.

DE PAIVA, A. C. G, CHAVES, P. T. C., \& ARAÚJO, M. E. 2008. Estrutura e organização trófica da ictiofauna de águas rasas em um estuário tropical. Revista Brasileira de Zoologia, 25, $647-661$.

DE QUEIROZ, J. D., SALVADOR, N. L., SOUSA, M. F., DA SILVA, V. E., FABRÉ, N. N. \& BATISTA, V. S. 2018. Lifehistory traits of Chloroscombrus chrysurus (Actinopterygii: Perciformes: Carangidae) in tropical waters of the Atlantic Ocean. Acta Ichthyologica Et Piscatoria, 48, 1-8.

DIAS NETO, J. 2011. Proposta de Plano Nacional de Gestão para o uso Sustentável de Camarões Marinhos do Brasil. Brasília, DF. IBAMA

DUARTE, G. A. S. \& ANDREATA, J. V. 2003. Hábito alimentar das espécies de achiridae e cynoglossidae que ocorrem na Baía da Ribeira, Angra dos Reis, Rio de Janeiro, Brasil. Bioikos (PUC-Campinas), 17, 39-48.

EDUARDO, L. N., LIRA, A. S., FRÉDOU, T., \& FRÉDOU, F. L. 2018. Population structure and reproductive biology of Haemulopsis corvinaeformis (Perciformes, Haemulidae) in the south coast of Pernambuco, northeastern Brazil. Iheringia. Série Zoologia, 108, e2018007. 
EDUARDO, L. N., FRÉDOU, T., LIRA, A. S., SILVA, L. V., FERREIRA, B. P., BERTRAND, A., MÉNARD, F. \& LUCENA-FRÉDOU, F. 2019. Length-weight relationship of thirteen demersal fishes from the tropical Brazilian continental shelf. Journal of Applied Ichthyology, 35(2), 590-593.

ELLIOTT, M., WHITFIELD, A. K., POTTER, I. C., BLABER, S. J. M., CYRUS, D. P., NORDLIE, F. G. \& HARRISON, T. D. 2007. The guild approach to categorizing estuarine fish assemblages: a global review. Fish and Fisheries, 8, 241-268.

FERREIRA, V., LE LOC'H, F., MÉNARD, F., FRÉDOU, T. \& FRÉDOU, F. L. 2019. Composition of the fish fauna in a tropical estuary: the ecological guild approach. Scientia Marina, 83, 133-142.

FRANCO, A., ELLIOTT, M., FRANZOI, P. \& TORRICELLI, P. 2008. Life strategies of fishes in European estuaries: The functional guild approach. Marine Ecology Progress Series, 354, 219-228.

FREIRE, K. M. F., ROCHA, G. R. A. \& SOUZA, I. L. 2009. Length-weight relationships for fishes caught by shrimp trawl in southern Bahia, Brazil. Journal of Applied Ichthyology, 25, 356-357.

FROESE, R. \& BINOHLAN, C. 2000. Empirical relationships to estimate asymptotic length, length at first maturity and length at maximum yield per recruit in fishes, with a simple method to evaluate length frequency data. Journal of Fish Biology, $56,758-773$.

FROESE, R. 2006. Cube law, condition factor and weight-length relationships: history, meta-analysis and recommendations. Journal of Applied Ichthyology, 22, 241-253.

FROESE, R., TSIKLIRAS, A. C. \& STERGIOU, K. I. 2011. Editorial note on weight-length relations of fishes. Acta Ichthyologica Et Piscatoria, 41, 261-263.

GARRISON, L. P., \& LINK, J. S. (2000). Dietary guild structure of the fish community in the Northeast United States continental shelf ecosystem. Marine Ecology Progress Series, 202, 231-240.

GIARRIZZO, T., JESUS, A. J. S., LAMEIRA, E. C., ALMEIDA, J. B. A., ISAAC, V. \& SAINT-PAUL, U. 2006. Weight-length relationships for intertidal fish fauna in a mangrove estuary in Northern Brazil AN. Journal of Applied Ichthyology, 22, 325-327.

GIARRIZZO, T. \& KRUMME, U. 2007. Spatial differences and seasonal cyclicity in the intertidal fish fauna from four mangrove creeks in a salinity zone of the Curuçá estuary, north Brazil. Bulletin of Marine Science, 80, 739-754.

HAZEN, E. L., SCALES, K. L., MAXWELL, S. M., BRISCOE, D. K., WELCH, H., BOGRAD, S. J., BAILEY, H., BENSON, S. R., EGUCHI, T., DEWAR, H., KOHIN, S., COSTA, D. P., CROWDER, L. B. \& LEWISON, R. B. 2018. A dynamic ocean management tool to reduce bycatch and support sustainable fisheries. Science Advances, 4, eaar3001.

ICMBIO (Instituto Chico Mendes de Conservação da Biodiversidade). 2008. Livro Vermelho Livro Vermelho da Fauna Brasileira. In: Livro Vermelho da Fauna Brasileira Ameaçada de Extinção. Brasília, DF: ICMBio: Instituto Chico Mendes de Conservação da Biodiversidade.

IGFA (International Game Fish Association). 2001. Database of IGFA angling records until 2001. Fort Lauderdale: International Game Fish Association.
KULLANDER, S.O. AND C.J. FERRARIS JR., 2003. Family Engraulididae (Anchovies). p. 39-42. In R.E. Reis, S.O. Kullander and C.J. Ferraris, Jr. (eds.) Checklist of the Freshwater Fishes of South and Central America. Porto Alegre: EDIPUCRS, Brasil.

LE BAIL, P. Y., KEITH, P. \& PLANQUETTE, P., 2000. Atlas des poissons d'eau douce de Guyane, Tome 2, Paris, Muséum National d'Histoire Naturelle.

LIRA A.S., VIANA A.P., EDUARDO L.N., LUCENA-FRÉDOU F., FRÉDOU T. Population structure, size at first sexual maturity, and feeding ecology of Conodon nobilis (Perciformes, Haemulidae) from the coast of Pernambuco, Northeastern Brazil. Acta Ichthyologica et Piscatoria, v.49, n.4, 2019 (In press).

LIRA A.S., VIANA A.P., FREDOU, F.L., et al. 2013a. Determinação do hábito alimentar de isophisthus parvipinis (Curvier, 1830) (Actinopterygii: Sciaenidae) na região de Barra de Sirinhaém PE. XVIII Congr. Bras. Eng. Pesca, Pernambuco, Brazil

LIRA, A. S., VIANA, A. P., NOLÉ, L. E., LUCENA FRÉDOU, F. \& FRÉDOU, T. 2013b. Hábito alimentar do Menticirrhus americanus (Linnaeus, 1758) (Actinopterygii: Sciaenidae) na região de Barra de Sirinhaém PE. In: XVIII Congresso Brasileiro de Engenharia de Pesca. Paulo Afonso, PE, October 20-24 2013.

LOPES, P. R. D. \& OLIVEIRA-SILVA, J. T. 1998. Notes on the feeding of Conodon nobilis (Linnaeus) and Polydactylus virginicus (Linnaeus) (Actinopterygii: Haemulidae e Polynemidae) in the Jaguaribe Beach (Itamaraca' Island), state of Pernambuco. Bioikos, 12, 53-59.

MAI, A. C. G. \& VIEIRA, J. P. 2013. Review and consideration on habitat use, distribution and life history of Lycengraulis grossidens (Agassiz, 1829) (Actinopterygii, Clupeiformes, Engraulididae). Biota Neotropica, 13, 121-130.

MENDES, F. L. S. \& BARTHEM, R. B. 2010. Hábitos alimentares de bagres marinhos (siluriformes: ariidae) do estuário amazônico. Amazônia: Ciência \& Desenvimento, 5, 153-166.

MENDOZA-CARRANZA, M. 2013. The feeding habits of gafftopsail catfish Bagre marinus ( Ariidae ) in Paraiso Coast, Tabasco, Mexico. Hidrobiológica, 13, 119-126.

MENEZES, N. A. \& FIGUEIREDO, J. L. 1980. Manual de peixes marinhos do sudeste do Brasil. IV. Teleostei (3), São Paulo, Museu de Zoologia da Universidade de São Paulo.

MILITELLI, M. I. \& MACCHI, G. J. 2004. Spawning and fecundity of king weakfish, Macrodon ancylodon, in the Río de la Plata estuary, Argentina-Uruguay. Journal of the Marine Biological Association of the United Kingdom, 84, 443-447.

MOTOMURA, H. 2004. Threadfins of the world, Rome, FAO.

MOURÃO, K. R. M., FERREIRA, V. \& LUCENA-FRÉDOU, F. 2014. Composition of functional ecological guilds of the fish fauna of the internal sector of the amazon estuary, pará, Brazil. Anais da Academia Brasileira de Ciências, 86, 17831800 .

MUTO, E. Y., CORBISIER, T. N., COELHO, L. I., ARANTES, L. P. L., CHALOM, A. \& SOARES, L. S. H. 2014. Trophic groups of demersal fish of Santos Bay and adjacent continental shelf, São Paulo State, Brazil: Temporal and spatial comparisons. Brazilian Journal of Oceanography, 62, 89-102. 
MUTO, E. Y., MALFARA, D. T., COELHO, L. I. \& SOARES, L. S. H. 2008. Alimentação das sardinhas Pellona harroweri (Fowler, 1919) e Chirocentrodon bleekerianus (Poey, 1867), na região costeira de Santos, Estado de São Paulo. In: BRAGA, E. S. (org.) Oceanografia e mudanças globais. São Paulo: Instituto Oceanográfico.

NICOLAS, D., LOBRY, J., LE PAPE, O. \& BOËT, P. 2010. Functional diversity in European estuaries: Relating the composition of fish assemblages to the abiotic environment. Estuarine, Coastal and Shelf Science, 88, 329-338.

NIZINSKI, M. S. \& MUNROE, T. A. 2002. Order Clupeiformes, Engraulididae. In: CARPENTER, K. E. (ed.) FAO Species Identification Guide for Fishery Purposes. The Living Marine Resources of the Western Central Atlantic. Rome: FAO.

PAIVA, A. C. G, LIMA, M. F. V, SOUZA, J. R. B. \& ARAÚJO, M. E. 2009. Spatial distribution of the estuarine ichthyofauna of the Rio Formoso (Pernambuco, Brazil), with emphasis on reef fish. Zoologia (Curitiba), 26, 266-278.

PASCOE, S. 1997. Bycatch management and the economics of discarding. FAO Fisheries Technical Paper, Rome, FAO.

PASSOS, A. C., CONTENTE, R. F., ABBATEPAUlO, F. V, SPACH, H. L., VILAR, C. C., JOYEUX, J. C., CARTAGENA, B. F. C. \& FAVARO, L. F. 2013. Analysis of fish assemblages in sectors along a salinity gradient based on species, families and functional groups. Brazilian Journal of Oceanography, 61, 251-264.

PETERMANN, A. \& SCHWINGEL, P. R. 2016. Overlap of the reproductive cycle and recruitment of the four main species caught by the purse seine fleet in Brazil. Latin American Journal of Aquatic Research, 44, 1069-1079.

PINHEIRO-SOUSA, D. B., SILVA, N. K., PIOSKI, N. M., ROCHA, A. C. G., CARVALHO- NETA, R. N. F. \& ALMEIDA, Z. S. 2015. Feeding habits and reproductive aspects of Bagre bagre (Siluriformes, Ariidae) in a coast of São Luís island, Maranhão, Brazil. Revista Brasileira de Engenharia de Pesca, 8, 1-12.

POMBO, M., DENADAI, M. R. \& TURRA, A. 2013. Seasonality, dietary overlap and the role of taxonomic resolution in the study of the diet of three congeneric fishes from a tropical bay. PLoS ONE, 8, e56107.

POMBO, M., DENADAI, M. R., BESSA, E., SANTOS, F. B., FARIA, V. H. \& TURRA, A. 2014. The barred grunt Conodon nobilis (Perciformes: Haemulidae) in shallow areas of a tropical bight: Spatial and temporal distribution, body growth and diet. Helgoland Marine Research, 68, 271-279.

RAMOS, L. A. 2006. Auto-ecologia de lycengraulis grossidens (Agassiz, 1829)(Clupeiformes, Engraulididae) em estuários do Rio Grande do Sul e sua pescana Barra do Rio Tramandai, RS, Brasil [thesis]. Rio Grande: Universidade Federal do Rio Grande.

RIEDE, K. 2004. Global register of migratory species: from global to regional scales: final report of the R\&D-Projekt 80805 081, Bonn, Federal Agency for Nature Conservation.

RODRIGUES-FILHO, J., VERANI, J., PERET, A., SABINSON, L. \& BRANCO, J. 2011. The influence of population structure and reproductive aspects of the genus Stellifer (Oken, 1817) on the abundance of species on the southern Brazilian coast. Brazilian Journal of Biology, 71, 991-1002.
SANTOS, L. N., BROTTO, D. S. \& ZALMON, I. R. 2011. Assessing artificial reefs for fisheries management: a 10-year assessment off Northern coast of Rio de Janeiro. In: BORTONE, S. A., BRANDINI, F. P., FABI, G. \& OTAKE, S (eds.) Artificial Reefs in Fisheries Management. Boca Raton: CRC Press.

SANTOS, M. C. F., PEREIRA, J. A. \& IVO, C. T. C. 2006. A pesca do camarão branco Litopenaeus schmitti (Burkenroad, 1936) (Crustacea, Decapoda, Penaeidae) no nordeste do Brasil. Boletim Técnico Científico do CEPENE, 14, 33-58.

SCHMIDT, T. C. D. S. \& DIAS, J. F. 2012. Pattern of distribution and environmental influences on the scienidae community of the southeastern Brazilian coast. Brazilian Journal of Oceanography, 60, 233-243.

SHIPP, R. L. 1981. Tetraodontidae. In: FISCHER, W., BIANCHI, G. \& SCOTT, W. B. (eds.) FAO species identification sheets for fishery purposes. Eastern Central Atlantic; fishing areas 34, 47 (in part), 4. Department of Fisheries and Oceans Canada and FAO. Rome: FAO.

SILVA, J. T. O. \& LOPES, P. R. D. 2002. Notas sobre a alimentação e morfologia do aparelho digestivo de Chloroscombrus chrysurus (Linnaeus, 1766) (Actinopterygii, Carangidae) na Praia de Ponta da Ilha (Ilha de Itaparica, Bahia). Revista Brasileira de Zoociências, 4, 179-192.

SILVA JÚNIOR, C. A. B., ARAÚJO, M. E. \& FEITOSA, C. V. 2013. Sustainability of capture of fish bycatch in the prawn trawling in northeastern Brazil. Neotropical Ichthyology, 11, 133-142.

SILVA JÚNIOR, C. A. B., VIANA, A. P., FRÉDOU, F. L. \& FRÉDOU, T. 2015. Aspects of the reproductive biology and characterization of Sciaenidae captured as bycatch in the prawn trawling in the northeastern Brazil. Acta Scientiarum. Biological Sciences, 37, 1-8.

SOETH, M., FÁVARO, L. F., SPACH, H. L., DAROS, F. A., WOLTRICH, A. E. \& CORREIA, A. T. 2019. Age, growth, and reproductive biology of the Atlantic spadefish Chaetodipterus faber in southern Brazil. Ichthyological Research, 66, 140-154.

SPACH, H. L., SANTOS, C., GODEFROID, R. S., NARDI, M. \& CUNHA, F. 2004. A study of the fish community structure in a tidal creek. Brazilian Journal of Biology, 64, 337-351.

TAYLOR, W. R. \& MENEZES, N. A. 1978. Ariidae. In: FISCH$\mathrm{ER}, \mathrm{W}$. (ed.) FAO species identification sheets for fishery purposes. West Atlantic (Fishing Area 31). Rome: FAO.

VASCONCELOS-FILHO, L. A. NEUMANN-LEITÃO, S., ESKINAZI-LEÇA, E., OLIVEIRA, A. M. E. \& ORTO-NETO, F. F. 2009. Hábitos alimentares de consumidores primários da ictiofauna do sistema estuarino de itamaracá (Pernambuco Brasil). Revista Brasileira de Engenharia de Pesca, 4, 21-31.

VASCONCELOS FILHO, A. L., NEUMANN LEITÃO, S., ESKINAZI-LEÇA, E. \& OLIVEIRA, A. M. E. 2010. Hábitos alimentares de peixes consumidores secundários do Canal de Santa Cruz, Pernambuco, Brasil. Tropical Oceanography, 38, 122-129.

VASCONCELOS FILHO, A. L.; OLIVEIRA, A. M. E. 1999. Composição e ecologia da ictiofauna do Canal de Santa Cruz (Itamaracá-PE, Brasil). Trabalhos Oceanográficos da UFPE, $27,101-113$. 
VASCONCELOS FILHO, A. L. 1979. Estudo Ecológico da Região de Itamaracá, Pernambuco, Brasil. IV. Alimentação da Sardinha Bandeira, Opisthonema oglinum (Le Sueur, 1817), no Canal de Santa Cruz. Trabalhos Oceanográficos da UFPE, 14, 105-116.

VAZ-DOS-SANTOS, A. M. \& ROSSI-WONGTSCHOWSKI, C. L. D. B. 2013. Length-weight relationships of the ichthyofauna associated with the Brazilian sardine, Sardinella brasiliensis, on the Southeastern Brazilian Bight $\left(22^{\circ} \mathrm{S}-29^{\circ} \mathrm{S}\right)$ between 2008 and 2010. Biota Neotropical, 13, 326-330.
VÉRAS, P. F. \& ALMEIDA, Z. S. 2016. Biologia reprodutiva do Bagre bagre capturado pela pescaria de zangaria. Revista Brasileira de Ciências Agrárias, 11, 367-373.

ZAHORCSAK, P., SILVANO, R. A. M. \& SAZIMA, I. 2000. Feeding biology of a guild of benthivorous fishes in a sandy shore on south-eastern Brazilian coast. Revista Brasileira de Biologia, 60, 511-518. 